\title{
THE UNBROKEN SUPREMACY OF THE CANADian CONSTITUTION
}

\begin{abstract}
BRIAN BIRD*
This article revives the awareness of the heritage and inheritance of section 52(1) of the Constitution Act, 1982. It exposes the pre-1982 legal basis for constitutional judicial review in Canada and the mechanics of the transition in 1982 to an express supremacy clause. This article also challenges two popular notions in Canadian constitutional law today. The first is that the addition of section 52(1) in 1982 transformed Canada from a state governed by parliamentary supremacy into a state governed by constitutional supremacy. The second is that the Canadian judiciary became the guardian of the Canadian Constitution in 1982. Contrary to conventional wisdom, 1982 was, with respect to the supremacy of the Canadian Constitution, a moment of continuity rather than a break with the past.
\end{abstract}

TABLE OF CONTENTS

I. INTRODUCTION . . . . . . . . . . . . . . . . . . . 755

II. CANADA AND THE Colonial LAWS VALIDITY ACT, $1865 \ldots \ldots \ldots \ldots \ldots .757$

III. CANADA AND THE StATUTE of WeStMinsteR, $1931 \ldots \ldots \ldots \ldots \ldots \ldots$

IV. A LAPSE IN SUPREMACY? . . . . . . . . . . . . . . . . . . . . . 763

V. CANADA AND THE 1982 MOMENT . . . . . . . . . . . . . . . . . 768

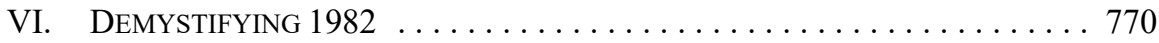

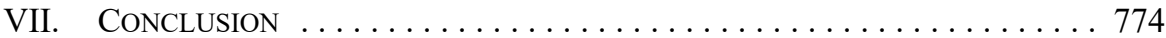

\section{INTRODUCTION}

Since 1982, the Canadian Constitution has featured an express supremacy clause. Section 52(1) of the Constitution Act, 1982 declares that the Canadian Constitution is "the supreme law of Canada, and any law that is inconsistent with the provisions of the Constitution is, to the extent of the inconsistency, of no force or effect." Canadian courts have invoked section 52(1) since 1982 as the legal basis for invalidating unconstitutional laws enacted by legislatures in Canada. Yet, before 1982, Canadian courts also engaged in constitutional judicial review - at that time, on the basis that other aspects of the Constitution, especially the British North America Act, $1867,{ }^{2}$ formed part of the supreme law of Canada.

The practice of constitutional judicial review in Canada before 1982, without an express supremacy clause, raises intriguing questions. On what legal basis did Canadian courts engage in this practice before 1982? What is the origin of constitutional judicial review in Canada?

Doctor of Civil Law Candidate, McGill University. This article was first presented at a symposium on the Canadian Constitution in May 2017 at Scuola Superiore Sant'Anna in Pisa, Italy.

Constitution Act, 1982, s 52(1), being Schedule B to the Canada Act 1982 (UK), 1982, c 11 [Constitution Act]. The contents of the "Canadian Constitution" are stated in section 52(2).

Constitution Act, 1867 (UK), 30 \& 31 Vict, c 3, reprinted in RSC 1985, Appendix II, No 5 [BNA Act]. Originally enacted as the British North America Act, 1867, this statute was retitled the Constitution Act, 1867 as part of the patriation of the Canadian Constitution in 1982. Given the historical nature of this article, I have opted for an abbreviation that reflects the statute's original title. 
While there was no equivalent to section 52(1) in the Canadian Constitution before 1982, a de facto supremacy clause resided in a British statute: the Colonial Laws Validity Act, 1865. ${ }^{3}$ This statute invalidated colonial legislation that was repugnant to British legislation applicable to that colony (an example for Canada being the BNA Act). The Statute of Westminster, 1931 liberated Canada from the restrictions of the 1865 statute but effectively preserved the supremacy of the BNA Act in Canada. ${ }^{4}$ This preservation continued until 1982, when the baton passed to the express supremacy clause in section 52(1) of the Constitution Act. While some Canadian courts and legal scholars have acknowledged the legal heritage of section 52(1) and the role it inherited, awareness of this feature of Canadian constitutionalism has faded.

This article revives awareness of the heritage and inheritance of section 52(1). It exposes the pre-1982 legal basis for constitutional judicial review in Canada and the mechanics of the transition in 1982 to an express supremacy clause. This article also challenges two popular notions in Canadian constitutional law today. The first is that the addition of section 52(1) in 1982 transformed Canada from a state governed by parliamentary supremacy into a state governed by constitutional supremacy. The second is that the Canadian judiciary became the guardian of the Canadian Constitution in 1982. The practice of judicial review of legislation in Canada for constitutionality before 1982 undermines both notions. While the legal basis for the supremacy of the Canadian Constitution has changed at certain moments of Canadian history, the Canadian Constitution has always been the supreme law of Canada.

This article has five parts. The first part considers the origin of the supremacy of the Canadian Constitution: the Colonial Laws Validity Act, 1865. This British statute voided colonial statutes that were inconsistent with British legislation applicable to a colony (for example, the BNA Act). The second part examines the Statute of Westminster, 1931, which freed Canadian legislatures from the restrictions of the 1865 statute except in relation to the BNA Act (thereby preserving the supremacy of the Canadian Constitution). ${ }^{5}$ The third part considers whether the Statute of Westminster, 1931, as a matter of statutory interpretation, succeeded in preserving the supremacy of the Canadian Constitution between 1931 and 1982. The fourth part analyzes Canada's constitutional moment of 1982, focusing on how the express supremacy clause in section 52(1) of the Constitution Act came to be. The fifth part challenges two notions in Canadian constitutional law that have taken hold due to a fading awareness of the heritage and inheritance of section 52(1): that, as of 1982, (1) Canada transformed from a state governed by parliamentary supremacy to constitutional supremacy and (2) the Canadian judiciary became the guardian of the Constitution. 


\section{CANAdA ANd the Colonial LaWS VALidity ACt, 1865}

The CLVA, enacted in 1865 by the United Kingdom Parliament, bears the long title of "An Act to remove Doubts as to the Validity of Colonial Laws." ${ }^{\prime 6}$ The intent of the CLVA is uncontroversial. As the long title suggests, the CLVA is concerned with validating colonial laws. More precisely, the CLVA validated laws enacted by British colonies to the extent that these laws were consistent with British laws that applied to the colonies.

The interplay between colonial laws and British laws prior to the CLVA provides helpful context. By the middle of the 19th century, it was understood that legislatures in British colonies could not enact laws that were repugnant to the "fundamental principles of English law." Colonial and British courts were, by that time, invalidating colonial laws because of such repugnancy. ${ }^{8}$ There was a lack of certainty, however, on which principles of English law were fundamental and which were not. The CLVA settled the issue "by providing that no colonial laws should be invalid by reason of repugnancy to any rule of English law except a statute extending to the colony." The CLVA was a direct response to the problem of judges in British colonies invalidating colonial laws because of their inconsistency with British laws without regard to whether the British laws in question were intended to apply to the colony.

One judge, Justice Benjamin Boothby of the Supreme Court of South Australia, was especially problematic in this regard. In the decade or so leading up to the enactment of the CLVA, Justice Boothby applied in his rulings a version of repugnancy that went far beyond concern for colonial compliance with the "fundamental principles of English law." In one case, he declared that the Parliament of South Australia "had no power to override the common law of England." 10 This version of repugnancy meant that any laws enacted by the Legislature of South Australia that conflicted with any British statute or principle of common law were invalid, regardless of whether the statute or principle in question was intended to apply to South Australia. Among the South Australian statutes that Justice Boothby invalidated was the Real Property Act of 1858, which established the Torrens system of land registration in the colony. The influence of the situation in South Australia on the UK's decision to enact the CLVA is revealed by the final clause of the statute: it expressly confirmed the validity of the laws enacted in South Australia. ${ }^{11}$ No other British colony is specifically named in the CLVA. Justice Boothby continued to cause problems for the South Australian government after the CLVA was enacted. For example, he challenged the authority of the Attorney General and the appointment of judges to the Supreme Court of South Australia for reason of not being British-trained barristers. The government initiated proceedings to remove Justice Boothby from office. On 29 June 1867, the meddlesome judge

CLA, supra note 3.

Enid Campbell, "Colonial Legislation and The Laws of England" (1965) 2 U Tasm L Rev 148 at 148. See also DB Swinfen, Imperial Control of Colonial Legislation, 1813-1865: A Study of British Policy Towards Colonial Legislative Powers (Oxford: Clarendon Press, 1970).

Barry L Strayer, The Canadian Constitution and the Courts: The Function and Scope of Judicial Review, 3rd ed (Toronto: Butterworths, 1988) at 5-14 [Strayer, The Canadian Constitution]. See also Mary Sarah Bilder "Colonial Constitutionalism and Constitutional Law" in Alfred L Brophy \& Daniel W Hamilton, eds, Transformations in American Legal History: Essays in Honor of Morton J. Horwitz (Cambridge: Harvard University Press, 2009) 28.

$9 \quad R v$ Secretary of State for Foreign and Commonwealth Affairs, [2008] UKHL 61 at para 36.

$10 \quad$ Liebelt $v$ Hunt (1861), cited in Swinfen, supra note 7 at 171.

$11 \quad C L V A$, supra note 3 , s 7. 
was removed from office. He appealed the decision to the Privy Council, but died before the appeal could be heard. ${ }^{12}$

The CLVA thus clarified that the "only laws of England which stood in the way of colonial legislation were those statutes which specifically or by implication applied to the colony."13 James Mallory describes the CLVA as "a liberating statute, since it reduced the number of colonial laws which could be held null and void to those which were repugnant to such English statute law as applied to the colonies." 14 In other words, if a British law applying to Canada said "X," then a Canadian law that said "not X" would be invalid (or, in the words of the CLVA, "absolutely void and inoperative" $"$ ). Section 2 of the CLVA articulates this principle:

Any Colonial Law which is or shall be in any respect repugnant to the provisions of any Act of Parliament extending to the Colony to which such law may relate, or repugnant to any Order or Regulation made under Authority of such Act of Parliament, or having in the Colony the Force and Effect of such Act, shall be read subject to such Act, order, or regulation, and shall, to the extent of such repugnancy, but not otherwise, be and remain absolutely void and inoperative. ${ }^{16}$

In 1867, two years after the enactment of the CLVA, the UK Parliament enacted the BNA Act. The BNA Act created a confederation between the Provinces of Ontario, Quebec, Nova Scotia, and New Brunswick. The BNA Act is a pillar of the Canadian Constitution and the date that it came into force, 1 July 1867, is commonly called the birthday of Canada. As the BNA Act certainly applied to Canada, this meant, by virtue of the CLVA, that any Canadian law that was inconsistent with the BNA Act would be invalid to the extent of the inconsistency.

Most of the Canadian jurisprudence between 1867 and 1982 in which Canadian courts invalidated legislation for violating the BNA Act concerns the distribution of legislative power between the federal and provincial governments in Canada. Sections 91 and 92 of the BNA Act distribute legislative power between the two levels of government in Canada by subject matter. To give a sample of the distribution, the federal government can legislate in relation to topics such as marriage and divorce, navigation and shipping, and criminal law, whereas the provinces can legislate in relation to topics such as property and civil rights, the administration of justice, and municipalities. Apart from the division of legislative power, there are few other provisions of the BNA Act that limit legislative power in Canada. ${ }^{17}$ The

12 For an account of the saga concerning Justice Boothby, see John McLaren, Dewigged, Bothered, \& Bewildered: British Colonial Judges on Trial, 1800-1900 (Toronto: University of Toronto Press, 2011) at 193-216. See also John M Williams, "Justice Boothby: A Disaster That Happened" in George

13 Winterton, ed, State Constitutional Landmarks (Annandale, NSW: Federation Press, 2006) 21-52. Essential Readings in Canadian Constitutional Politics (Toronto: University of Toronto Press, 2011) 7 at 19

14 Ibid. The Supreme Court of Canada described the CLVA in similar terms in Re: Resolution to amend the Constitution, [1981] 1 SCR 753 at 794.

CLVA, supra note 3 , s 2 .

Ibid.

Section 93 of the BNA Act, supra note 2, for example, grants legislative jurisdiction over education to the Provinces but places limits on the exercise of that jurisdiction in relation to denominational schools. This section, along with sections 91 and 92, concerns the federal-provincial division of legislative power. Other sections of the BNA Act impose manner and form requirements on how legislative power is exercised: see e.g. ibid, ss 53-57, 133 . 
BNA Act does not feature a supremacy clause resembling section 52(1) of the Constitution Act. While sections 91 and 92 of the BNA Act delineate the matters of exclusive legislative power enjoyed by the federal and provincial governments, there is no stated consequence for violating this delineation.

There is an abundance of jurisprudence between 1867 and 1982 concerning whether federal or provincial legislation complies with the distribution of legislative power in the BNA Act. When Canadian courts determined that a statute violated this distribution, they would commonly declare the statute ultra vires - beyond the powers of the government that enacted it. At times, Canadian courts would also declare statutes to be null, void, or inoperative (for reason of their being ultra vires). The various combinations of words in these judicial declarations do not appear to suggest a difference in their effect. In each instance, the law under scrutiny is invalidated because the legislature that enacted it was not empowered to do so.

Curiously, between 1867 and 1982, Canadian courts rarely cited the CLVA when invalidating legislation for inconsistency with the BNA Act. A search for "Colonial Laws Validity Act" in LexisNexis Quicklaw yields 149 decisions in which that statute is mentioned. Among those 149 cases, only 49 were decided before 1982. Only a handful of those 49 cases feature the application of the CLVA to invalidate legislation for inconsistency with the BNA Act. ${ }^{18}$

Despite the relative absence of the CLVA in this jurisprudence, Barry Strayer, in his work on judicial review in Canada, argues that the CLVA was the legal basis for judicial invalidation of laws that violated the BNA Act. He argues that when "a Canadian court struck down a statute for constitutional invalidity, it was inarticulately applying the [CLVA], holding void the Canadian statute for repugnancy to the provisions of the [BNA Act] distributing power between Parliament and Legislatures." 19 Strayer is one of the few Canadian legal scholars to have considered the topic of this article in depth. His scholarship, therefore, is an important resource.

Despite the relative invisibility of the CLVA between 1867 and 1982 in Canadian constitutional jurisprudence, there are a handful of cases during this time period in which Canadian courts explicitly acknowledged the CLVA as the legal basis for invalidating Canadian legislation that was repugnant to the BNA Act. ${ }^{20}$ In a case from 1901, the Exchequer Court noted that the CLVA "applies in the case of an Act of the Parliament of the UK, extending to Canada, and passed after [the BNA Act]; and that any Canadian legislation on the same subject repugnant thereto is void." ${ }^{21}$ In a case from 1926, a court in Ontario noted that the exclusive jurisdiction of the Ontario Legislature over education in that Province under the BNA Act must respect the guarantee in section 93(1) of the BNA Act concerning denominational schools for Catholics. The Court held that any "provincial

This search was conducted on LexisNexis Quicklaw on 13 August 2017.

Strayer, The Canadian Constitution, supra note 8 at 7.

$R v$ Chandler (1868), 2 Cart 421 (NBSC); Pope v Griffith (1872), 2 Cart 291 (Que QB); Re Dansereau (1875), 2 Cart 165 at 190 (Que QB); L'Union St Jacques v Belisle (1872), 1 Cart 72 (Que QB), rev'd [1874] UKPC 53, 6 LRPC 31.

$21 \quad$ Algoma Central Railway Co v R (1901), 7 Ex CR 239 at 254. 
legislation repugnant to this provision" is absolutely void and inoperative due to the CLVA. ${ }^{22}$ In another case from 1926, at a time when it was the final court of appeal for Canada, the Judicial Committee of the Privy Council relied on the CLVA to invalidate a Canadian statute - a federal statute of 1888 that abolished criminal appeals to the Privy Council — for inconsistency with a British statute that applied to Canada. ${ }^{23}$

The view that the CLVA served as the legal basis for constitutional judicial review in Canada between 1867 and 1982 is reinforced by a number of Supreme Court of Canada decisions rendered shortly after the adoption of an express supremacy clause in the Canadian Constitution in 1982. These decisions also acknowledge that a later British statute — the Statute of Westminster, 1931 — played a role in the supremacy of the Canadian Constitution before 1982.

In R. v. Big M Drug Mart Ltd., the Supreme Court held that relevant provisions of the CLVA and the Statute of Westminster had been "replaced by s. 52(1) of the Constitution Act, 1982." ${ }^{24}$ In Operation Dismantle Inc. v. R., the Court held that section 52(1) appears "to have the same role in terms of imposing a constitutional limitation on law-making power in Canada as its predecessors": namely, the CLVA and the Statute of Westminster. ${ }^{25}$ In Reference Re Manitoba Language Rights, the Court explained the passing of the baton from the CLVA to the Constitution Act:

The constitutional jurisprudence, developed under the [CLVA], was based on the invalidity doctrine. If Parliament or a provincial legislature was ultra vires its constitutionally allocated powers in enacting a certain Act, then the repugnancy of that Act with the provisions of the [BNA Act] would mean that the Act was "absolutely void and inoperative."

Section 52 of the Constitution Act, 1982 does not alter the principles which have provided the foundation for judicial review over the years. In a case where constitutional manner and form requirements have not been complied with, the consequence of such non-compliance continues to be invalidity. The words "of no force or effect" mean that a law thus inconsistent with the Constitution has no force or effect because it is invalid. ${ }^{26}$

I agree with Strayer: where Canadian courts did not cite the CLVA before 1982 as the legal basis for invalidating Canadian legislation that was inconsistent with the BNAAct, they were inarticulately applying the CLVA. While Canadian courts rarely cited the CLVA between 1867 and 1982 as the specific legal basis for invalidating Canadian legislation featuring an inconsistency with the BNA Act, the prevailing opinion is that the CLVA was that legal basis. This position is recognized in recent Canadian jurisprudence. In 2015, the Federal Court of Appeal identified the CLVA as the legal basis before 1982 for judicial invalidation of laws that violated the BNA Act. ${ }^{27}$ The Court held that, from Confederation onward, "all Canadian courts ... could measure legislation up against laws of the Parliament of the United

Tiny Separate School Trustees v The King (1926), 59 OLR 96 at 97.

Nadan $v$ The King, [1926] UKPC 13, [1926] AC 482.

[1985] 1 SCR 295 at 313 [Big M Drug Mart].

[1985] 1 SCR 441 at 482. See also Gerald V La Forest, "The Canadian Charter of Rights and Freedoms:

An Overview" (1983) 61 Can Bar Rev 19 at 28.

[1985] 1 SCR 721 at 746 [Manitoba Language Rights].

Canadian Transit Co $v$ Windsor (City), 2015 FCA 88, 384 DLR (4th) 547 at para 56 [Canadian Transit]. 
Kingdom, including the $[B N A A c t]$, and determine whether they were invalid or inoperative." 28

Before considering the arrival of an express supremacy clause for the Canadian Constitution in 1982, there is another statute - one to which the Supreme Court of Canada referred in the rulings from the $1980 \mathrm{~s}$ - that played an important role regarding the supremacy of the Canadian Constitution before 1982: the Statute of Westminster. ${ }^{29}$

\section{CANADA AND THE STATUTE OF Westminster, 1931}

In 1931, the UK Parliament enacted the Statute of Westminster. The statute ratified agreements made between the UK and the British colonies that attended the Imperial Conferences of 1926 and 1930 (Canada, Australia, New Zealand, South Africa, the Irish Free State, Newfoundland, and India). Except for India, these colonies were referred to as "Dominions." The final report of the 1926 Conference, known as the "Balfour Declaration of 1926," represented a major step in the evolution of these Dominions from colonies to independent states. The Declaration stated that the Dominions would henceforth be empowered to legislate extra-territorially and that the UK would no longer legislate in relation to a Dominion unless it requested that the UK do so. The Declaration also proclaimed the equality of the Dominions in relation to one another as members of the British Empire:

They are autonomous Communities within the British Empire, equal in status, in no way subordinate one to another in any aspect of their domestic or external affairs, though united by a common allegiance to the Crown, and freely associated as members of the British Commonwealth of Nations. ${ }^{30}$

The Statute of Westminster formalized this statement through provisions that modified the ability of the UK to govern these Dominions (except for India, to which the Statute of Westminster does not apply). For that reason, the Statute of Westminster is often cited as authority for the proposition that, in 1931, Canada (and the other Dominions) gained greater independence and autonomy from the UK. The Statute of Westminster empowered the Dominions to legislate extra-territorially. ${ }^{31}$ It also prohibited the UK from enacting legislation that would apply to a Dominion "unless it is expressly declared" in such legislation that "the Dominion has requested, and consented to, the enactment thereof." 32 That provision explains why the Parliament of Canada had to ask the UK to enact the Canada Act, 1982 to patriate the Canadian Constitution and entrench the Canadian Charter of Rights and Freedoms, and why the UK Parliament was required to specify Canada's request in the text of the Canada Act, 1982 (the statute that gave effect to this patriation and entrenchment).

Ibid.

Statute of Westminster, supra note 4.

Commonwealth, Inter-Imperial Relations Committee, Imperial Conference 1926 (E(IR/26) Series) at 3, online: Museum of Australian Democracy $<$ https://www.foundingdocs.gov.au/resources/transcripts/ cth11 doc 1926.pdf>.

Supra note 4 , s 3 .

Ibid, s 4. 
The Statute of Westminster also released the Dominions from the legislative restrictions imposed by the CLVA. In other words, colonial legislation would no longer be void and inoperative due to inconsistency with British statutes applying to these colonies. Section 2 of the Statute of Westminster confirms this change:

(1) The Colonial Laws Validity Act, 1865, shall not apply to any law made after the commencement of this Act by the Parliament of a Dominion.

(2) No law and no provision of any law made after the commencement of this Act by the Parliament of a Dominion shall be void or inoperative on the ground that it is repugnant to the law of England, or to the provisions of any existing or future Act of Parliament of the United Kingdom, or to any order, rule or regulation made under any such Act, and the powers of the Parliament of a Dominion shall include the power to repeal or amend any such Act, order, rule or regulation in so far as the same is part of the law of the Dominion. $^{33}$

As the Ontario Court of Appeal noted in a ruling from 2014, "the Statute of Westminster was a significant development for Canadian sovereignty, in that it permitted Canada to pass laws that were inconsistent with certain British laws for the first time." 34 More precisely, legislatures in Canada could now enact laws inconsistent with British laws whether the British laws applied to Canada or not. To illustrate the effect of section 2 of the Statute of Westminster, the Parliament of Canada did in 1933 what it could not do in 1888: enact legislation that abolished criminal appeals to the Judicial Committee of the Privy Council (in other words, enact a Canadian statute that was inconsistent with a British statute that applied to Canada). ${ }^{35}$

The release in the Statute of Westminster from the legislative restrictions of the CLVA, if left unqualified, would have allowed legislatures in Canada to enact laws that were inconsistent with any British statute - including the BNA Act. In other words, legislatures in Canada could have enacted legislation that did not comply with the BNA Act - the core of the Canadian Constitution at that time. The BNAAct would, in short, no longer be supreme in Canada.

Had this scenario been permitted, it would have also unleashed political chaos in Canada. The federal and provincial governments had failed to agree on a formula for amending the BNA Act. Formal attempts to reach such an agreement had started after the 1926 Imperial Conference at the 1927 Federal-Provincial Conference in Ottawa. Several attempts were made after the Statute of Westminster was enacted to craft a workable amending formula, but

Ibid, s 2.

McAteer v Canada (Attorney General), 2014 ONCA 578, 121 OR (3d) 1 at para 45.

An Act to amend the Criminal Code, SC 1932-33, c 53, s 17. The Judicial Committee of the Privy Council upheld this legislation in British Coal Corp v R, [1935] UKPC 33, [1935] AC 500. It subsequently confirmed, in a reference case, that the Parliament of Canada could enact legislation abolishing civil appeals to that body: Ontario (AG) v Canada (AG), [1947] UKPC 1, [1947] AC 127. In 1949, the Parliament of Canada enacted such legislation: An Act to amend the Supreme Court Act, SC 1949 (2nd session), c 37, s 3. 
an agreement on this issue was not reached until the patriation of the Canadian Constitution in $1982 .{ }^{36}$

Given the threat posed by section 2 of the Statute of Westminster to the supremacy of the BNA Act and the spectre of political chaos in Canada due to the lack of a domestic amending formula, section 7 of the Statute of Westminster was included to preserve the supremacy of the BNA Act and to keep the power of amending the BNA Act in the hands of the UK:

(1) Nothing in this Act shall be deemed to apply to the repeal, amendment or alteration of the British North America Acts, 1867 to 1930 , or any order, rule or regulation made thereunder.

(2) The provisions of section two of this Act shall extend to laws made by any of the Provinces of Canada and to the powers of the legislatures of such Provinces.

(3) The powers conferred by this Act upon the Parliament of Canada or upon the legislatures of the Provinces shall be restricted to the enactment of laws in relation to matters within the competence of the Parliament of Canada or of any of the legislatures of the Provinces respectively. ${ }^{37}$

While section 7 of the Statute of Westminster is often said to have continued the supremacy of the BNA Act, there is reason to question whether section 7 achieved that result. It is arguable, on a strict reading of section 7 , that it only partially preserved the supremacy of the Canadian Constitution between 1931 and 1982.

\section{A Lapse in Supremacy?}

Section 7(1) of the Statute of Westminster declares that nothing in that statute "shall be deemed to apply to the repeal, amendment or alteration of the British North America Acts, 1867 to 1930 , or any order, rule or regulation made thereunder." 38 This provision must be read together with section 2(2), which gave the Dominions the power (1) to enact legislation that is repugnant to the laws of England and (2) to repeal or amend any English laws forming part of the law of the Dominion. ${ }^{39}$ Section 7(1) appears to qualify only the second of these powers. It does not qualify the power of the Dominions granted by section 2(2) to enact laws that are inconsistent with British laws. ${ }^{40}$ Without section $7(1)$, legislatures in Canada would

36 Noel Cox, Constitutional Paradigms and the Stability of States (Abingdon: Routledge, 2012) at 130. See also Canada, Privy Council Office (Intergovernmental Affairs), "Why, in 1931, Canada Chose Not to Exercise its Full Autonomy as Provided for Under the Statute of Westminster" (Ottawa: Intergovernmental Affairs, 21 August 2017), online: <www.canada.ca/en/intergovernmental-affairs/ services/federation/statute-westminster.html>.

37 Statute of Westminster, supra note $4, \mathrm{~s} 7$.

$38 \quad$ Ibid, s 7(1). Section 7(1) refers to the "British North America Acts, 1867 to 1930." There are indeed several British North America Acts (starting with the BNA Act in 1867), some of which remain part of the Canadian Constitution: see Constitution Act, supra note 1, s 53 (Schedule to the Constitution Act, 1982). Further British North America Acts were enacted after 1931 (some by the UK Parliament and some by the Canadian Parliament). Certain Acts were repealed or amended in 1982 when the Canadian Constitution was patriated; others were repealed earlier. The British North America Act, 1916 (UK), 6 \& 7 Geo V, c 19, for example, was repealed in 1927.

39 Statute of Westminster, supra note 4, s 2(2).

40 The point is that section 7(1) does not seem to prevent legislatures in Canada from enacting legislation that is inconsistent with the BNA Act - it only prohibits the amendment of the BNA Act by these legislatures. That said, if Canadian legislation that is inconsistent with the BNA Act could be considered an implied repeal of the BNA Act, then perhaps section 7(1) does some work to preserve the supremacy of the BNA Act in Canada between 1931 and 1982. 
have been free to repeal or amend the BNA Act (which was, at that time, the core of the Canadian Constitution). Section 7(1) confirmed that the power to amend the BNA Act remained exclusively with the UK Parliament, but the provision does not obviously preserve the supremacy of the BNA Act in Canada.

Section 7(2) of the Statute of Westminster provides that section 2 of the same statute "shall extend to laws made by any of the Provinces of Canada and to the powers of the legislatures of such Provinces." ${ }^{41}$ As with section 7(1), this section must be read together with section 2. Section 2, by itself, could be interpreted to apply only to the (federal) Parliament of Canada. It says the "Parliament of a Dominion" 42 is freed from the CLVA and is thus immune from having any legislation it enacts invalidated for repugnancy to the laws of England. Section 2 is unclear as to whether the Provinces enjoy this freedom and immunity, but section 7(2) confirms that they do. Kenneth Wheare, in his text on the Statute of Westminster, agrees that the "fetter imposed by the [CLVA] upon the Parliament of Canada had thus been removed by section 2" of the Statute of Westminster, and the "same fetter imposed upon the legislatures of the Provinces of Canada had been removed by section 7(2)." ${ }^{, 43}$ The point is that, like section 7(1) of the Statute of Westminster, section 7(2) does nothing to preserve the supremacy of the BNA Act in Canada.

Section 7(3) declares that the "powers conferred by this Act upon the Parliament of Canada or upon the legislatures of the Provinces shall be restricted to the enactment of laws in relation to matters within the competence of the Parliament of Canada or of any of the legislatures of the Provinces respectively." 44 The arguable effect of section 7(3) is that the distribution of legislative power between the federal and provincial governments in the BNA Act remained, after 1931, a matter for which Canadian courts could invalidate legislation. In his commentary on the Statute of Westminster in 1932, Robert Mahaffy states, with respect to section 7(3), that the "areas of legislative competence of Canada and the Provinces are, of course, delimited by the historic sections 91 and 92 of the Act of $1867 .{ }^{״ 45}$

There is judicial support in Canada for the proposition that section 7(3) of the Statute of Westminster maintained the ability of Canadian courts to invalidate legislation for noncompliance with the federal-provincial distribution of legislative power in the BNA Act. In a 1981 ruling on the amount of provincial support needed to amend the Canadian Constitution, the Supreme Court of Canada referred on three occasions to section 7(3) and its "preservation" of "the existing distribution of legislative power under" the BNA Act. ${ }^{46}$ In 2015, the Federal Court of Appeal acknowledged that section 7(3) maintained the supremacy of the BNA Act (at least with respect to the distribution of legislative power between the federal and provincial legislatures). ${ }^{47}$ Curiously, section 7(3) was not repealed in 1982 when

Supra note 4, s 7(2).

Ibid, s 2.

KC Wheare, The Statute of Westminster and Dominion Status, 5th ed (Oxford: Oxford University Press, $1953)$ at 186.

Statute of Westminster, supra note 4, s 7(3).

Robert P Mahaffy, The Statute of Westminster 1931 (London: Butterworth, 1932) at 13.

Re: Resolution to amend the Constitution, supra note 14 at $797,835,847$. In an earlier decision, the Court made the same observation regarding section 7(3) of the Statute of Westminster: see Reference Re legislative jurisdiction of Parliament of Canada to enact the Minimum Wages Act, [1936] SCR 461 at 535-36.

47 Canadian Transit, supra note 27 at paras 59-60. 
an express supremacy clause was inserted into the Canadian Constitution (whereas section 7(1) was repealed). It may be that the constitutional drafters did not fully appreciate the contribution of section 7(3) in 1982.

Section 7(3) of the Statute of Westminster seems to have preserved the supremacy of the Canadian Constitution to the extent of authorizing Canadian courts to continue invalidating legislation that violated the distribution of legislative power in the BNA Act. But what about the provisions of the BNA Act that limit legislative power in ways unrelated to the distribution of legislative power between the federal and provincial governments? Section 121 of the BNA Act is an example: "All Articles of the Growth, Produce, or Manufacture of any one of the Provinces shall, from and after the Union, be admitted free into each of the other Provinces." ${ }^{\prime 4}$ This provision equally binds the federal and provincial legislatures. The provision does not demarcate spheres of legislative power between levels of government rather, it limits legislative power equally across Canada. Did section 7(3) of the Statute of Westminster maintain the supremacy of a provision like section 121 of the BNA Act? If not, there would seem to have been no bar, given section 2 of the Statute of Westminster, to Canadian legislatures enacting statutes that are inconsistent with section 121 of the BNA Act from 1931 until 1982 (when the express supremacy clause arrived).

One response to this threat to the supremacy of the BNA Act would be to interpret section 7(3) such that "matters within the competence of" legislatures in Canada means that the enactment of laws that violate any provision of the BNA Act fall outside of that "competence." The difficulty is that, aside from the demarcation of federal and provincial legislative power, there are no other explicit limits in the BNA Act on Canadian legislatures to enact legislation that is inconsistent with that statute. The Statute of Westminster freed the legislatures of the Dominions from the CLVA, which until then had forbidden these Dominions from legislating in a manner inconsistent with British legislation extending to these Dominions. This principle is the starting point. Any exceptions to it must be found elsewhere in the Statute of Westminster. Only section 7(3) appears to preserve the effect of the CLVA vis-à-vis the BNA Act, but arguably only with respect to the division of legislative power between the federal and provincial governments. Canadian courts have interpreted section 7(3) as speaking to this division of legislative power in the BNA Act.

Another response to the possibility that the Statute of Westminster only partially preserved the supremacy of the BNA Act after 1931 is to argue that the judicial practice of invalidating laws before 1982 was based on something other than the repugnancy doctrine in the CLVA. As there is no mention of a power of judicial review in the BNA Act, the basis for judicial review in Canada between 1867 and 1982 has been a matter of debate. ${ }^{49}$ There are a number of competing theories on this issue. One, advocated by Strayer, is the repugnancy theory under the CLVA (and later the Statute of Westminster).$^{50}$ Another, advocated by scholars such

Jennifer Smith, "The Origins of Judicial Review in Canada" (1983) 16:1 Can J Political Science 115. Since the early 1990s, there has been little scholarship on this question. The presence of an express supremacy clause in the Canadian Constitution justifying judicial review since 1982 may explain (at least in part) the loss of scholarly interest in the subject.

50 Strayer, The Canadian Constitution, supra note 8 at 1-14. 
as Norman Siebrasse, is the excess of jurisdiction (ultra vires) theory. ${ }^{51}$ There is also the theory, which has not gained traction in Canada, that judicial review is justified at common law "by the courts' own constitutional responsibility for the rule of law." ${ }^{, 2}$ Whereas Strayer argues that Canadian courts (for the most part) inarticulately applied the CLVA when they invalidated laws that were inconsistent with the BNA Act, Siebrasse argues that the lack of reference to the CLVA by Canadian courts suggests that the CLVA was not the legal basis for the practice. In his view, the "excess of jurisdiction was clearly the prevalent justification for judicial review" in Canada. ${ }^{53}$

The excess of jurisdiction (ultra vires) theory of judicial review is grounded in the intent of Parliament. The phrase ultra vires in this context means "beyond the powers that Parliament intended the agency to have." 54 This theory asserts, in other words, that the "constitutional justification for judicial review ... is that the courts are giving effect to limitations that were imposed by Parliament when it granted the power." ${ }^{55}$ In the case of the BNA Act, this theory of judicial review says that the UK Parliament intended (when it enacted the BNA Act) for legislatures in Canada to respect the limitations imposed by this statute on their powers and for the courts to enforce that respect, where necessary, through judicial review. Even the advocates of this theory (such as Siebrasse) concede that, in Canada, any practical distinction between excess of jurisdiction and repugnancy has been "so fine as to be invisible." 56 Although Canadian courts have often used the phrase ultra vires when declaring laws unconstitutional, it is not obvious that this practice reveals their acceptance of the excess of jurisdiction theory of judicial review.

The majority of scholarly and judicial opinion favours the repugnancy theory, grounded in the CLVA, as the legal basis for judicial review in Canada between 1867 and $1982 .{ }^{57}$ One reason why may be the fact that at the time of Confederation the practice of judicial review did not exist in the UK. The foundational principle of the British Constitution, famously stated by scholars such as A.V. Dicey, is the sovereignty of Parliament. From the principle of parliamentary sovereignty springs the principle that "British courts do not have the power to review and invalidate legislation" by Parliament. ${ }^{58}$ The preamble to the BNA Act declares that Canada has a constitution "similar in principle" to that of the UK. Despite the absence of judicial review in the UK and Canada's receipt of a constitution similar to that of the UK, judicial review began in Canada "immediately after Confederation" with little controversy. ${ }^{59}$ In these circumstances, the only obvious legal basis for judicial review in Canada after

$51 \quad$ Norman Siebrasse, "The Doctrinal Origin of Judicial Review and the Colonial Laws Validity Act” (1993) 1:1 Rev Const Stud 75. Another position appears to be that the repugnancy and excess of jurisdiction theories were alternate (but equally valid) bases of judicial review in Canada between 1867 and 1982: see H McD Clokie, "Basic Problems of the Canadian Constitution" (1942) 20:10 Can Bar Rev 817 at 833.

52 Timothy Endicott, "Constitutional Logic" (2003) 53:2 UTLJ 201 at 202. Canadian courts have described safeguarding the rule of law as a purpose of (rather than a legal basis for) judicial review: see e.g. Dunsmuir v New Brunswick, 2008 SCC 9, [2008] 1 SCR 190 at paras 163-64.

53 Siebrasse, supra note 51 at 76.

Endicott, supra note 52 at 201 [emphasis in original]. For a critique of the ultra vires theory of judicial review, see Paul Craig, "Ultra Vires and the Foundations of Judicial Review" (1998) 57:1 Cambridge LJ 63.

55 Endicott, ibid at 201 [emphasis in original].

Siebrasse, supra note 51 at 92.

Peter W Hogg, Constitutional Law of Canada: 2016 Student Edition (Toronto: Thomson Reuters, 2016) at $3-3$ to $3-9,5-22$ to $5-26.1$.

Paul C Weiler, “The Supreme Court of Canada and Canadian Federalism” (1973) 11:2 Osgoode Hall LJ 225 at 234.

Ibid. 
Confederation is the CLVA. That statute, enacted two years before the BNAAct, clarified the scope of judicial review of colonial legislation for compliance with British laws - a practice that was well-established by the time of Confederation and one that courts in Canada continued after $1867 .^{60}$

It is indeed difficult to reconcile the excess of jurisdiction theory of pre-1982 judicial review with the explicit recognition by the Supreme Court of Canada of the heritage of the express supremacy clause that arrived in 1982. These statements favour the repugnancy doctrine as the basis for constitutional judicial review in Canada prior to 1982. The clearest statement of support may be from Manitoba Language Rights (a statement that also happens to describe ultra vires as a feature of the repugnancy theory rather than a distinct and competing theory):

The constitutional jurisprudence, developed under the [CLVA], was based on the invalidity doctrine. If Parliament or a provincial legislature was ultra vires its constitutionally allocated powers in enacting a certain Act, then the repugnancy of that Act with the provisions of the [BNA Act] would mean that the Act was "absolutely void and inoperative.",61

If the repugnancy theory under the CLVA was the only legal basis for judicial review in Canada after 1867, we are thus left with the possibility that the Statute of Westminster only partially preserved the supremacy of the BNAAct between 1931 and 1982. More specifically, a strict reading of sections 2 and 7 of the Statute of Westminster reveal that the legislation may have only preserved the supremacy of the BNA Act with respect to the distribution of legislative power between the federal and provincial governments. If that is the case, it endangers the legitimacy of any judicial invalidation of legislation between 1931 and 1982 for inconsistency with the BNA Act that is unrelated to the federal-provincial distribution of legislative power. ${ }^{62}$

However, in the final analysis, it is widely accepted that the intent of section 7 of the Statute of Westminster was to preserve, through the CLVA, the supremacy of the BNA Act in Canada. It is difficult to imagine that the conventional wisdom regarding the effect of section 7 of the Statute of Westminster — on a matter as fundamental as the supremacy of

60 Ibid. See also Strayer, The Canadian Constitution, supra note 8 at 20-21; Frederick L Morton, ed, Law, Politics and the Judicial Process in Canada (Calgary: University of Calgary Press, 2002) at 424-25. Morton makes this point at 424:

Originally, judicial review of the constitution came easily and without controversy in Canada. The [BNA Act] took the form of an Imperial statute, and section 129 mandated the continuation of the existing legal regime. This meant that the [BNA Act] was subject to the already existing [CLVA], which required consistency of colonial law with British Imperial statutes. The Judicial Committee of the Privy Council was charged with the responsibility of enforcing this policy. The Judicial Committee had served as the final court of appeal for British North America prior to Confederation, and simply continued in this capacity after 1867. Any alleged violation of the federal division of powers set out in the [BNA Act] could be challenged in the existing superior courts of the provinces and appealed from a provincial court of appeal directly to the Judicial Committee in London.

$61 \quad$ Manitoba Language Rights, supra note 26 at 746.

62 An example is Quebec (AG) v Blaikie, [1979] 2 SCR 1016. The Supreme Court of Canada invalidated a Quebec statute that required the Quebec Legislature to draft and enact bills only in French. The Court held that the statute violated section 133 of the BNA Act, which requires, inter alia, that the laws of Quebec be enacted in English and French. It is notable, given the wording of section 7(3) of the Statute of Westminster, that the Court held that "it was beyond the competence of the Quebec Legislature to modify unilaterally the prescriptions" of section 133 of the BNA Act (ibid at 1019). 
the BNA Act in Canada - would be incorrect. The concern I have raised - a possible lapse in the supremacy of the Canadian Constitution - may simply be a product of careless legislative drafting. While section 7(3) appears to have maintained the power of courts to invalidate legislation that violated the division of powers in the BNA Act, it is arguable that legislation enacted in Canada that violates any aspect of the BNA Act is an implied repeal, amendment, or alteration of the BNA Act and thus contrary to section 7(1) of the Statute of Westminster. If that interpretation holds water, then the supremacy of the Canadian Constitution was preserved between 1931 and 1982, at which point the express supremacy clause arrived.

\section{CANAda AND The 1982 Moment}

After the enactment of the Statute of Westminster in 1931, the next year of significance for the supremacy of the Canadian Constitution (and for the Canadian Constitution in general) is 1982. On 17 April 1982, the Constitution Act took effect in Canada. Gil Remillard has summarized the main consequences of this statute:

1) It severed Canada's last colonial link to the United Kingdom by establishing a completely Canadian amendment procedure.

2) It amended the original federative compromise of 1867 by incorporating a Charter of Rights and Freedoms, an amendment procedure, an equalization principle and regional disparities, a recognition of aboriginal rights, and amendments concerning the division of legislative authority in the area of natural resources. ${ }^{63}$

In 1982, the Canadian Constitution came home - or, to use more formal language, it was patriated. This homecoming meant that the Canadian Constitution could be amended in Canada using the new amending formula. Between 1867 and 1982, constitutional amendments could not be made in Canada. This power had resided with the UK Parliament. With the enactment of the Canada Act, 1982 by the UK Parliament, that power ended. ${ }^{64}$ That statute contains the text of the Constitution Act (in which the amending formula is found). It also contains the Canadian Charter of Rights and Freedoms, a bill of rights that was added to the Canadian Constitution. ${ }^{65}$

While it is accurate to state that a comprehensive domestic amending formula for the Canadian Constitution took effect in 1982, there is an important (and often overlooked) moment in 1949 concerning the domestic amendment of the Canadian Constitution. At the request of the Parliament of Canada, the UK empowered Parliament to make a limited variety of amendments to the Canadian Constitution by enacting the British North America (No. 2) Act, 1949. ${ }^{66}$ This statute amended the portion of the BNA Act concerning the legislative jurisdiction of the federal government to allow the "amendment from time to time of the Constitution of Canada" (followed by a list of matters in respect of which the federal 
government was not permitted to amend the Canadian Constitution) ${ }^{67} \mathrm{With}$ this power, the Parliament of Canada enacted the British North America Acts of 1952, 1965, 1974, 1975, and 1975 (No. 2). These statutes addressed a range of matters, including the establishment of a mandatory retirement age for Senators and giving the Yukon Territory its own Member of Parliament.

Returning to 1982, the Constitution Act was "never enacted by any legislative body in Canada. ${ }^{\circ 6}$ It is, rather, a schedule to the Canada Act (a statute that was enacted by the UK Parliament). Section 1 of the Canada Act stipulates that the statute enjoys "the force of law in Canada." ${ }^{69}$ The preamble notes that the UK Parliament enacted the Canada Act at the request of Canada and with its consent. As was the case from 1867 until 1982, Canadian courts have, since 1982, reviewed legislation for consistency with the Constitution. The legal basis for this judicial practice has, since 1982, been section 52(1) of the Constitution Act: "The Constitution of Canada is the supreme law of Canada, and any law that is inconsistent with the provisions of the Constitution is, to the extent of the inconsistency, of no force or effect." ${ }^{70}$ Section 52(1) assumed the role first held by the CLVA and subsequently by the Statute of Westminster. The scholarship of Strayer on this issue deserves our attention. Strayer was Canada's Assistant Deputy Minister of Justice from 1974 to 1983, and an important figure in the crafting of the constitutional patriation package of 1982. He later served as a judge on the Federal Court (both Trial Division and Court of Appeal) and as Chief Justice of the Court Martial Appeal Court. Strayer, who also taught law at the University of Saskatchewan, is one of the few Canadian legal scholars to have extensively considered the source of the supremacy of the Canadian Constitution before 1982. In his part-professional autobiography and part-work of Canadian legal history, Strayer confirms that section 52(1), the explicit legal basis for the supremacy of the Canadian Constitution and for constitutional judicial review in Canada since 1982, was included to avoid a lapse in the supremacy of the Canadian Constitution.

Strayer, then at the Department of Justice, explained how that lapse in supremacy almost occurred during the lead up to the patriation of the Constitution. He recounts that the drafters intended to repeal section 7(1) of the Statute of Westminster as part of the 1982 constitutional package - the provision that in his view had, since 1931, "preserved for our constitution the supremacy rule in section 2 " of the CLVA. ${ }^{71}$ The original text of section 52 of the Constitution Act did not feature a supremacy clause. It simply identified the contents of the "Constitution of Canada." 72 The problem was that the CLVA did not mention that term - it did not use the "Constitution of Canada" as a reference point for supremacy. Without an updated supremacy clause, therefore, there would be no obvious legal basis upon which

Ibid, s 1 .

Peter W Hogg, "Supremacy of the Canadian Charter of Rights and Freedoms" (1983) 61:1 Can Bar Rev 69 at 71.

Canada Act, supra note 64, s 1 .

Constitution Act, supra note 1, s 52(1).

Barry L Strayer, Canada's Constitutional Revolution (Edmonton: University of Alberta Press, 2013) at 164. As the earlier analysis of section 7 reveals, it is somewhat peculiar that section 7(1), and not section 7(3), of the Statute of Westminster is considered the provision that most immediately preserved the supremacy of the BNA Act in Canada.

See Constitution Act, supra note 1, s 52(2). 
Canadian courts could continue to invalidate legislation for inconsistency with the Canadian Constitution. Strayer describes his awakening to this reality:

\begin{abstract}
It suddenly struck me one morning in early September of 1980, as I was shaving, that the structure we had in mind for patriation might eliminate that rule. While in the provision that became section 52 we had described the statutes that were specifically to be considered part of the Constitution of Canada, that description nowhere mentioned section 2 of the [CLVA]. Furthermore, it was our plan to seek the repeal of subsection 7(1) of the Statute of Westminster, 1931, which had so far preserved for our constitution the supremacy rule in section 2 of the [CLVA]. It therefore seemed important to reaffirm the constitutional supremacy principle in the revised constitution we were adopting. I asked for some work to be done on this in the Department, which confirmed my concerns. As a result, a declaration of the supremacy of the Constitution was added to section 52, paraphrasing Article VI, section 2 of the Constitution of the United States. $^{73}$
\end{abstract}

As mentioned earlier, during the 1980s the Supreme Court of Canada recognized section 52(1) as the successor to the relevant provisions of the CLVA and the Statute of Westminster. As time has passed, however, awareness of this relationship has faded. This fading awareness has inspired misleading notions in Canadian constitutionalism. I consider two in the remainder of this article.

\title{
IV. DEMYSTIFYING 1982
}

Appreciating the legal basis for the supremacy of the Canadian Constitution before 1982 challenges at least two ideas of what 1982 meant for Canada — ideas that are often described as implications of the express supremacy clause in section 52(1) of the Constitution Act. The first idea is that section 52(1) transformed Canada in 1982 from a state governed by parliamentary supremacy into a state governed by constitutional supremacy. The second idea is that the Canadian judiciary became the guardian of the Canadian Constitution as of 1982 . The occurrence of constitutional judicial review in Canada before 1982 undermines both ideas.

In Hunter v. Southam Inc., a decision from 1984, the Supreme Court of Canada described the judiciary as "the guardian of the Constitution." "The statement is ambiguous with respect to whether the Court meant that the judiciary became the guardian of the constitution as of 1982 or whether it held that status before. That said, the "as of 1982" understanding has taken hold in Canada. In a 2014 ruling, the Supreme Court cited Hunter together with the text of section 52(1) for the proposition that the judiciary "became" the guardian of the Constitution as of $1982 .^{75}$

As for Canada's transformation from a democracy governed by parliamentary supremacy to constitutional supremacy, in 1998 the Supreme Court held in Reference re Secession of Quebec that, with "the adoption of the Charter, the Canadian system of government was transformed to a significant extent from a system of Parliamentary supremacy to one of 
constitutional supremacy." "76 This statement glosses over the fact that Canada was, before 1982, governed by constitutional supremacy - the difference was the breadth of state action subject to constitutional oversight. The 1982 moment drastically expanded the scope of state action that would be scrutinized for constitutional compliance, especially in relation to individual rights and freedoms due to the adoption of the Charter. While one could argue that the statement of the Supreme Court in the Secession Reference bears this interpretation because of the phrase "to a significant extent," it is in my view neither the most immediate interpretation nor the interpretation that has taken hold. The conventional wisdom is that, after the 1982 moment (particularly after the adoption of the Charter), Canada transformed entirely from a system of parliamentary supremacy to a system of constitutional supremacy.

In Vriend v. Alberta, also from 1998, Justice Iacobucci of the Supreme Court articulates this conventional wisdom: "When the Charter was introduced, Canada went ... from a system of Parliamentary supremacy to constitutional supremacy."77 Justice Iacobucci, in making this declaration, cites a 1985 speech by then Chief Justice of Canada Brian Dickson. A close reading of this speech, however, reveals that the Chief Justice was alive to the supremacy of the Canadian Constitution before 1982 and the role played by Canadian judges as its guardian:

In Canada we have always had a written Constitution as the supreme law of the land. The recent Constitution Act, 1982 explicitly states that any laws inconsistent with the Constitution are of no force or effect to the extent of the inconsistency and thus grants the judiciary the mandate to review legislative action and declare it of no force or effect where it does not meet the requirements of the Constitution. Judicial review of legislation is not, however, new in Canada. Our written Constitution has always been justiciable and the Canadian judiciary has, from the earliest days of Confederation, not hesitated to declare invalid legislation repugnant to the Constitution. ${ }^{78}$

The statement of Justice Iacobucci in Vriend is therefore misleading. It is one example of when the Supreme Court of Canada has "waxed eloquently on the profound change in our constitutional system effected by section $52 \ldots$ and from this perceived fundamental change it has inferred a large license for the Court to redefine the contents of the constitution." ${ }^{, 79}$ The decision in Vriend is one of the most prominent examples of this redefinition. In Vriend, the Supreme Court invalidated a provision of Alberta's Individual Rights Protection Act ${ }^{80}$ because it neglected to prohibit discrimination based on sexual orientation - a feature that the Court concluded was inconsistent with the equality guarantee in section 15 of the Charter. The remedy selected by the Court caused some controversy. Rather than invalidate the law, the Court "read in" the ground of sexual orientation. For all intents and purposes, the Court amended the statute.

The remedy of "reading in" first appeared in the Supreme Court's 1992 ruling in Schachter v. Canada, a case involving parental benefits under a federal statute. ${ }^{81}$ The Court

[1998] 2 SCR 217 at para 72 [Secession Reference].

[1998] 1 SCR 493 at para 131 [Vriend].

The Right Honourable Chief Justice RGB Dickson, "Keynote Address" in Frank E McArdle, ed, The Cambridge Lectures 1985 (Montreal: Yvon Blais, 1987) 1 at 3.

Strayer, supra note 71 at 164.

RSA 1980 , c I-2.

[1992] 2 SCR 679 [Schachter]. 
identified reading in as a remedial option under section 52(1): "Depending upon the circumstances, a court may simply strike down, it may strike down and temporarily suspend the declaration of invalidity, or it may resort to the techniques of reading down or reading in." ${ }^{" 82}$ The Court noted that "reading in" should be used "only in the clearest of cases." ${ }^{" 83}$ The Court in Schachter cited no specific legal basis for the remedy of reading in other than section 52 of the Constitution Act. Section 52(1) simply declares the supremacy of the Constitution and that legislation which is inconsistent with the Constitution is "of no force or effect." If Canadian judges (after 1982) base the expansion of judicial remedies in constitutional litigation on the notions that Canadian courts became (as of 1982) the guardians of the Constitution and that Canada became a state governed by constitutional supremacy, this article has demonstrated that this approach is flawed. Both features applied in Canada prior to 1982.

There are signs that Canadian judges have pursued that line of thinking to expand their remedial toolbox in constitutional litigation after 1982. At times, this sort of thinking is a product of an understandable focus on what the adoption of the Charter meant for Canada and Canadian constitutionalism. In a ruling from 1991, the Supreme Court of Canada held that the "primary concern of the court" when selecting a remedy in a Charter case "must be to apply the measures that will best vindicate the values expressed in the Charter and to provide the form of remedy to those whose rights have been violated that best achieves that objective." ${ }^{\prime 4}$ This approach, which implies a "broad discretion to fashion" remedies in Charter cases, "flows from the court's role as guardian of the rights and freedoms which are entrenched as part of the supreme law of Canada" - a role derived from "an express mandate to declare invalid a law which, by virtue of s. $52 \ldots$ is of no force or effect to the extent of its inconsistency with the Charter." ${ }^{85}$ The message is that the adoption of the Charter not only enlarged the content of the supreme law of Canada: it also enlarged the range of remedies that courts can use to dispose of constitutional litigation.

The expansion of judicial remedies in constitutional litigation since 1982 has not been limited to Charter cases, however. The Manitoba Language Rights decision from 1985 is an example. That case determined that the BNA Act and the Manitoba Act, $1870^{86}$ obligated the Manitoba Legislature to enact all of its laws both in English and in French. Given that most of Manitoba's laws had only been enacted in English, the Supreme Court opted to temporarily suspend its declaration of the invalidity of these unilingual laws in order to give the Manitoba Legislature time to re-enact the laws in both official languages and to avoid a "legal vacuum ... with consequent legal chaos." " In a later decision, the Supreme Court acknowledged that the "remedial innovation" in Manitoba Language Rights was developed

Osborne v Canada (Treasury Board), [1991] 2 SCR 69 at 104 [Osborne].

Ibid. The statement that section 52 provides an "express mandate" for courts to invalidate unconstitutional legislation is odd given that section 52 makes no reference to the judiciary as being entrusted with that power.

Reprinted in RSC 1970, Appendix II, No 8.

Manitoba Language Rights, supra note 26 at 747. 
"notwithstanding the express terms of s. 52(1)," a provision which "suggests that declarations of invalidity can only be given immediate effect." 88

Returning to Vriend, Justice Iacobucci endorsed the view that there were changes in 1982 to the role of the judiciary and to the nature of Canadian democracy that created a wider remedial role for Canadian courts. Justice Iacobucci describes in Vriend what 1982 meant for the "relationship between legislatures and the courts in the age of the Charter." $89 \mathrm{He}$ identifies a "consequential remedial role" of courts to determine the constitutionality of legislation that flows from the adoption of the Charter - an identification which suggests that this role did not exist before 1982:

Our constitutional design was refashioned to state that henceforth the legislatures and executive must perform their roles in conformity with the newly conferred constitutional rights and freedoms. That the courts were the trustees of these rights insofar as disputes arose concerning their interpretation was a necessary part of this new design. ${ }^{90}$

Notably, Justice Iacobucci's discussion of the legislative and judicial relationship regarding the constitutionality of government action makes no reference to the practice of constitutional judicial review in Canada before 1982. While Canada's constitutional moment in 1982 was undoubtedly transformative, its elements of continuity have been overlooked.

Ironically, Justice Iacobucci relies on section 52(1) to support his view that the Canadian judiciary took on a new responsibility as of 1982. The decisions of the Supreme Court in the 1980s — Big M Drug Mart, Operation Dismantle, and Manitoba Language Rights confirm that the opposite is true. Rather than enlarge the role of the courts in constitutional affairs, section 52(1) was included to preserve the status quo in relation to the supremacy of the Canadian Constitution. Strayer, writing as a judge of the Federal Court of Appeal, makes this point:

If indeed before 1982 the Constitution of Canada, then consisting of the B.N.A. Acts and certain other provisions, was not supreme over federal and provincial laws, it is difficult to understand on what basis our courts, including the Supreme Court of Canada, had ever since Confederation exercised the jurisdiction to strike down such Canadian laws for inconsistency with the division of powers set out in sections 91 and 92 of the B.N.A. Act, 1867. Both before and after 1982 our system was and is one of parliamentary sovereignty exercisable within the limits of a written constitution. These were solely quantitative limits on the exercise of legislative power prior to 1982. It is true that the adoption of the Charter in 1982 added a multitude of qualitative limitations on the exercise of power but it is difficult to ascertain any change in the principle that the Constitution of Canada was and is supreme over ordinary laws. As a result one is driven as before 1982 to looking at the specific requirements of the Constitution to determine whether in a given case Parliament has infringed a constitutional limit (express or implied) on its power. ${ }^{91}$

Reference re Remuneration of Judges of the Provincial Court of Prince Edward Island; Referemce re Independence and Impartiality of Judges of the Provincial Court of Prince Edward Island, [1997] 3 SCR 3 at para 99.

$89 \quad$ Supra note 77 at para 129

$90 \quad$ Ibid at para 134.

$91 \quad$ Singh $v$ Canada (Attorney General), [2000] 3 FCR 185 at para 16. 
It appears that the source of the supremacy of the Canadian Constitution before 1982 is obscure to most Canadian jurists today. In my view, this phenomenon is at least partly due to the mystique that has come to surround the meaning of 1982 for Canadian constitutionalism and the role of the judiciary in constitutional litigation.

\section{Conclusion}

This article has identified the often overlooked and even forgotten legal basis used by Canadian courts to invalidate legislation for inconsistency with the Canadian Constitution before the arrival of an express supremacy clause in 1982. Between 1867 and 1982, this legal basis resided in two British statutes: the CLVA and the Statute of Westminster. It is fair to say, borrowing the words of Peter Russell, that the supremacy of the Canadian Constitution before 1982 was "based more on imperialism than on constitutionalism." ${ }^{.92}$ Canada's path to 1982 featured an evolution towards constitutionalism as the basis for constitutional supremacy. This path reached its end with the patriation of the Canadian Constitution in 1982, an element of which was the addition of a clause declaring the Constitution to be the "supreme law" of Canada and any law inconsistent with the Constitution to be "of no force or effect."

There is some uncertainty, on a strict reading, as to whether the Statute of Westminster entirely preserved the supremacy of the Canadian Constitution between 1931 and 1982. The Statute of Westminster arguably only preserved supremacy for the aspects of the Canadian Constitution concerning the division of federal and provincial spheres of legislative power. If so, then other aspects of the Canadian Constitution did not form part of the supreme law between 1931 and 1982. That said, it is quite clear that the Statute of Westminster preserved the Constitution's supremacy on the issue that generated most of the constitutional litigation before 1982: the division of legislative power between the federal and provincial governments. Moreover, as mentioned earlier, the concern regarding the Statute of Westminster and the supremacy of the Canadian Constitution may be a product of careless drafting of section 7 of that statute. The prevailing wisdom is that the intent of section 7 was to entirely preserve the supremacy of the Canadian Constitution as it existed at that time.

While Canadian courts rarely cited the CLVA and the Statute of Westminster in cases before 1982 that feature the invalidation of unconstitutional legislation, these statutes were the legal basis for this judicial practice. Section 52(1) of the Constitution Act inherited the role of the relevant provisions of these statutes that enabled this judicial practice. The Supreme Court of Canada recognized this inheritance shortly after Canada's constitutional moment of 1982. Regarding the debate over the origin of judicial review in Canada, the repugnancy theory has gained favour. I support this theory. Yet, regardless of which theory accurately explains the origin of judicial review in Canada, the express supremacy clause in section 52(1) is undoubtedly an updated version of the de facto supremacy clause in the CLVA that was later preserved in relation to the BNA Act by the Statute of Westminster. 
This article has also considered how the fading awareness of the legal basis for constitutional judicial review in Canada before 1982 has given life to certain misunderstandings of what 1982 meant: namely that (1) Canada transformed from a state governed by parliamentary supremacy to a state governed by constitutional supremacy and (2) the Canadian judiciary became the guardian of the Canadian Constitution. As the decision of Justice Iacobucci in Vriend illustrates, these misunderstandings have influenced judges in terms of how they remedy unconstitutional laws. I do not assert that the constitutional remedies which have emerged since 1982 are necessarily illegitimate. I simply highlight that the source of their legitimacy cannot be the unsound notions that, as of 1982, Canadian courts became the guardians of the Constitution and that Canada became governed by constitutional rather than parliamentary supremacy.

The notion that Canada "suddenly" became a nation governed by constitutional supremacy as of 1982 has "become the stuff of after-dinner speeches wherever lawyers are gathered, but it has no basis in reality." ${ }^{93}$ Section 52(1) does no more than "maintain the continuity of our system, which has known judicial review to enforce constitutional limitations on our legislatures and executives since before Confederation." ${ }^{" 94}$ Contrary to conventional wisdom, 1982 was, with respect to the supremacy of the Canadian Constitution, a moment of continuity rather than a break with the past. 
[this page is intentionally blank] 